\title{
Phytochemical profile and in vitro evaluation of extracts from leaves of Drimys brasiliensis (Winteraceae) against bovine and equine herpesviruses
}

\author{
Rafael Martins Parreira ${ }^{1,2}$, Isabela Cristina Simoni ${ }^{1 *}$, Oriana Aparecida Fávero ${ }^{2}$, João Henrique G. Lago ${ }^{3}$, \\ Murillo C. Mecchi ${ }^{3}$, Kaidu Hanashiro Barrosa ${ }^{3}$, Maria Judite Bittencourt Fernandes ${ }^{1}$ \\ ${ }^{1}$ Centro de P \& D de Sanidade Animal, Instituto Biológico/APTA-SAA, São Paulo, Brazil. ${ }^{2}$ Universidade Presbiteriana Mackenzie, São Paulo, Brazil. \\ ${ }^{3}$ Instituto de Ciências Ambientais, Químicas e Farmacêuticas, Universidade Federal de São Paulo, São Paulo, Brazil.
}

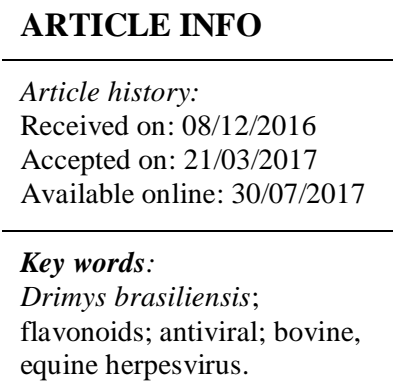

\begin{abstract}
Drimys brasiliensis Miers (Winteraceae) is an evergreen flowering plant found in the Atlantic Forest and has previously determined to have antifungal, antioxidant, and anti-inflammatory activities. The aim of this research is to describe the phytochemical profile and to evaluate the in vitro antiviral properties of crude extracts from leaves of D. brasiliensis, collected in different periods, against equine and bovine herpesviruses. Hydroalcoholic crude extracts were prepared from fresh leaves, collected bimonthly during one year (from August/2008 to June/2009). Phytochemically, these extracts showed to be composed of flavonoids, quercetrin, astilbin and isoastilbin. The antiviral activity was evaluated by viral cytopathic effect inhibitory assay and cytotoxicity assays were also done. All tested extracts displayed inhibitory effects against bovine herpesvirus without seasonal influence, but there was variation in their effect against equine herpesvirus. The results obtained in this study indicate that the extracts from leaves of D. brasiliensis exhibited significant antiviral activity against animal herpesviruses, indicating their potential for medicinal use.
\end{abstract}

\section{INTRODUCTION}

Viral infections are a serious threat to human and animal health worldwide, and are of major economic importance both in developed and in developing countries, mainly owing to its high mortality and morbidity rates. Viral epidemic diseases are a major source of mortality in cattle and horses. The search for new plant species for the prevention and possible treatment of diseases, as well as increasing the quality of animal origin food and improving public health by offering more nutritious and healthy plant-based foods, remains largely unexplored (Simoni et al., 2014). Medicinal plants have various substances that inhibit different parts of the replication cycles of various types of DNA and RNA viruses.

\section{* Corresponding Author}

Isabela Cristina Simoni, Centro de P \& D de Sanidade Animal, Instituto Biológico/APTA-SAA, São Paulo, Brazil.

E-mail: simoni @ biologico.sp.gov.br
This antiviral activity is generally attributed to polyphenols, rosmarinic acid, and low- molecular- weight glycoside compounds such as chlorogenic acid and caffeic acid (Jassimand Naji, 2003).

Substances present in plant extracts also interact with each other, altering the effect of a particular active ingredient (Gobbo-Neto and Lopes, 2007). Therefore, medicinal plants are an important resource in the search for new ways to combat and control diseases caused by herpesviruses in both humans and animals (Khan et al., 2005).

Some plant extracts have already been described to be inhibitors human and animal herpesvirus. Crude aqueous extract from Persea americana presented potential activity against HSV-1 and SuHV-1 (Almeida et al., 1998). Extracts from Thymus capitata showed efficient activity against BoHV-1 (Boubaker-Elandalousi et al., 2014). Essential oils from Drimys brasiliensis and D. angustifolia also showed antiviral activity against HSV-1(Gomes, et al., 2013). 
The Drimys genus of the Winteraceae family has the largest geographical distribution, with representatives in the Americas from the Southern of Argentina and Chile to Mexico. In Brazil, this genus is restricted to temperate regions from Bahia to Rio Grande do Sul (Abreu et al., 2005). Drimys species have been used in folk medicine, mainly in the form of bark infusions for the treatment of several ailments, including ulcers, cancer, pains, respiratory problems, and malaria (Limberger et al., 2007). Crude extracts and purified metabolites from D. brasiliensis displayed several biological activities including antifungal, antiinflammatory, antinociceptive, antinociceptive, antibacterial, antioxidant, antileishmanial, antimalarial, antitrypanosomal, and antiviral (Malheiros et al., 2005; Carvalho et al., 2008; Lago et al., 2010; Correa et al., 2010; Claudino et al., 2013; Gomes et al., 2013). Phytohemically, drimane sesquiterpenoids (poligodial and derivatives) have been isolated from the bark (Fratoni et al., 2016) whereas sesquiterpenoids and flavonoids were detected in the leaves (Mecchi and Lago, 2013).

Additionally, monoterpenes and sesquiterpenes were identified in essential oils from barks and leaves (Ribeiro et al., 2008; Lago et al., 2010; Lago et al., 2011).

Based on knowledge of the properties of D.brasiliensis, this study aimed to investigate the antiviral properties of polar extracts from this plant. Hydroalcoolic (EtOH:H2O 2:1) extracts from leaves of $\mathrm{D}$. brasiliensis obtained from six different collections during one year (bimonthly during August/2008 to June/2009) were prepared and assayed against animal herpesviruses.

Additionally, the extract obtained from leaves at August/2008 was subjected to chromatographic separation procedures to afford three flavonoids - astilbin, isoastilbin and quercetrin, which were characterized by NMR spectral analysis.

\section{MATERIALSAND METHODS}

\section{General experimental procedures}

Sephadex LH-20 (Sigma) was used for column chromatographic separations while silica gel $60 \mathrm{PF}_{254}$ (Merck) was used for analytical $(0.25 \mathrm{~mm})$ TLC. HPLC separation procedures were conducted in a Dionex Ultimate 3000 chromatograph couplet to UVD-17OU spectrophotometric detector (DAD) using analytical $(25 \times 4.6 \mathrm{~cm}, 5 \mu \mathrm{m})$ and semi-preparative $(25 \times 10 \mathrm{~cm}$, $5 \mu \mathrm{m})$, Phemomenex Luna $\mathrm{C}_{18}$ columns and mixtures of $\mathrm{MeOH}: \mathrm{H}_{2} \mathrm{O}$ as solvent. ${ }^{1} \mathrm{H}$ and ${ }^{13} \mathrm{C}$ NMR spectra were recorded at 300 and $75 \mathrm{MHz}$, respectively, in a Bruker AvanceIII300 spectrometer. DMSO- $\mathrm{d}_{6}$ (TediaBrazil) was used as solvents and as internal standard.

\section{Plant material}

D. brasiliensis leaves were collected in the region located at $22^{\circ} 46^{\prime} 24^{\prime \prime} \mathrm{S}$ e $45^{\circ} 33^{\prime} 45^{\prime}$ 'W in the Campos do Jordão by Prof. Oriana A. Fávero of Universidade Presbiteriana Mackenzie. Six bimonthly samples of leaves were collected for one year
(August/2008 to June/2009). A voucher specimen was deposited in the Herbarium of the City of São Paulo - PMSP8984 - identified by Dr. Lucia Rossi of Instituto de Botânica/SP.

\section{Preparation of crude extracts and isolation of main compounds}

Dried and powdered leaves (896 g) from collection of August/2008, were defatted using hexane $(5 \mathrm{X} 2 \mathrm{~L}$ at room temperature) and then exhaustively extracted with EtOH: $\mathrm{H}_{2} \mathrm{O}$ 2:1 at room temperature. After evaporation of the $\mathrm{EtOH}$ under reduced pressure followed by lyophilization, were obtained $66 \mathrm{~g}$ of crude extract. Part of this material $(10 \mathrm{~g})$ was ressuspended in $\mathrm{MeOH}: \mathrm{H}_{2} \mathrm{O}$ 2:1 and thenextracted with EtOAc to afford, after evaporation of solvent under reduced pressure, $8 \mathrm{~g}$ of EtOAc phase. Part ofthis phase (190 mg) was subjected to Sephadex LH20 column chromatography eluted with $\mathrm{MeOH}$ to yield three fractions $(\mathrm{A}-\mathrm{C})$. NMR spectra of fractions A $(65 \mathrm{mg})$ and $\mathrm{B}(71$ $\mathrm{mg}$ ) showed to be composed by free glycosides. Fraction C (40 $\mathrm{mg}$ ), composed by flavonoids as evidenced by NMR, was purified using $\mathrm{C}_{18}$ reversed-phase semi-prep. HPLC, eluted with MeOH: $\mathrm{H}_{2} \mathrm{O} 3: 7$ at a flow rate of $2.4 \mathrm{~mL} / \mathrm{min}$ (detection at 330 $\mathrm{nm}$ ), to afford $\mathbf{1}$ (quercitrin - $15 \mathrm{mg}$ ), 2 (astilbin - $12 \mathrm{mg}$ ) and $\mathbf{3}$ (isoalstilbin $-8 \mathrm{mg}$ ).

Quercitrin (1). Yellow solid. ${ }^{1} \mathrm{H}$ NMR (DMSO-d $\left.\mathrm{d}_{6}\right): \delta 7.34(\mathrm{~d}, J=$ $2.0 \mathrm{~Hz}, \mathrm{H}-2$ ') 7.30 (dd, $J=8.5$ and $2.1 \mathrm{~Hz}, \mathrm{H}-6$ '), 6.94 (d, $J=8.5$ Hz, H-5'), 6.37 (d, $J=2.0 \mathrm{~Hz}, \mathrm{H}-6), 6.19$ (d, $J=2.0 \mathrm{~Hz}, \mathrm{H}-8$ ), 5.34 (d, $J=1.5 \mathrm{~Hz}, \mathrm{H}-1$ "), $3.85-3.22$ (m, H-2" to H-5"), 0.94 (d, $J=6.0 \mathrm{~Hz}, \mathrm{H}-6 "$ "); ${ }^{13} \mathrm{C}$ NMR (DMSO-d 6 ): $\delta 177.4$ (C-4), 164.8 (C7), 161.3 (C-5), 157.2 (C-9), 156.5 (C-2), 148.5 (C-4'), 145.3 (C3'), 134.2 (C-3), 121.1 (C-1'), 120.7 (C-6'), 115.6 (C-5'), 115.5 (C-2'), 103.9 (C-10), 101.8 (C-1”), 98,9 (C-6), 93.7 (C-8), 71.2 (C-4”), 70.6 (C-3”), 70.4 (C-2”), 70.1 (C-5”), 17.5 (C-6”).

Astilbin (2). White amorphoussolid. ${ }^{1} \mathrm{H}$ NMR (DMSO- $\mathrm{d}_{6}$ ): $\delta 6.88$ (br s, H-2'), 6.74 (br s, H-5' and H-6'), 5.90 (d, J = 2.1 Hz, H-6), 5.88 (d, $J=2.1 \mathrm{~Hz}, \mathrm{H}-8), 5.24$ (d, $J=9.8 \mathrm{~Hz}, \mathrm{H}-2), 4.63$ (d, $J=9.8$ Hz, H-3), 4.07 (br s, H-1"), $3.80-3.40$ (m, H-2" to H-5"), 1.05 (d, $J=6.2 \mathrm{~Hz}, \mathrm{H}-6 ") ;{ }^{13} \mathrm{C}$ NMR (DMSO-d 6 ): $\delta 194.0$ (C-4), 168.1 (C7), 163.4 (C-5), 162.1 (C-9), 145.9 (C-3'), 145.1 (C-4'), 127.1 (C10), 118.9 (C-6'), 115.4 (C-5'), 114.7 (C-2'), 100.7 (C-10), 100.0 (C-1”), 96.3 (C-6), 95.4 (C-8), 81.5 (C-2), 75.6 (C-3), 71.1 (C-4”), 70.5 (C-3"), 70.1 (C-2”), 68.9 (C-5”), 17.7 (C-6”).

Isoastilbin (3). White amorphoussolid. ${ }^{1} \mathrm{H}$ NMR (DMSO- $\left.\mathrm{d}_{6}\right)$ : $\delta 6.86$ (d, $J=1.6 \mathrm{~Hz}, \mathrm{H}-2$ '), 6.73 (dd, $J=8.3$ and $1.6 \mathrm{~Hz}, \mathrm{H}-6$ '), 6.71 (d, $J=8.3 \mathrm{~Hz}, \mathrm{H}-5$ '), 5.93 (d, $J=2.0 \mathrm{~Hz}, \mathrm{H}-6), 5.90$ (d, $J=2.0 \mathrm{~Hz}, \mathrm{H}-$ 8), 5.53 (d, $J=2.6 \mathrm{~Hz}, \mathrm{H}-2), 4.22$ (d, $J=2.6 \mathrm{~Hz}, \mathrm{H}-3), 4.78$ (d, $J=$ $1.4 \mathrm{~Hz}, \mathrm{H}-1$ "), $3.80-3.40$ (m, H-2" to H-5”), 0.85 (d, J=6.2 Hz, H-6"); ${ }^{13}$ C NMR (DMSO-d 6 ): $\delta 192.5$ (C-4), 168.4 (C-7), 164.0 (C5), 162.4 (C-9), 145.1 (C-4'), 145.0 (C-3'), 126.5 (C-1'), 100.2 (C10), 117.6 (C-6'),115.0 (C-5'), 114.1 (C-2'), 98.8 (C-1'”), 96.4 (C- 
6), 95.6 (C-8), 79.9 (C-2), 73.4 (C-3), 71.4 (C-4"), 70.3 (C-2” andC-3"), 68.9 (C-5"), 17.5 (C-6").

\section{Cell lines and virus}

The cell lines MDBK (bovine kidney, ATCC-CCL 22) and Vero (monkey kidney, ATCC-CCL 81) were maintained in minimum Eagle medium (MEM) with $10 \%$ fetal bovine serum(FBS) (Fernandes and Simoni, 1995).The following viral strains were used: bovine herpesvirus (BoHV-1) or infectious bovine rhinotracheitis virus, Los Angeles strain (LA) (Simoni et al., 2007), and equine herpesvirus (EHV-1), A4/72strain (Moreira et al., 1998).

\section{Cytotoxicity assays}

The maximum non-toxic concentrations (MNTC) of the hydroalcoholic extracts from leaves of $\mathrm{D}$. brasiliensis were evaluated in MDBK and Vero cells using the method described by Simoni et al. (1996). Sterile and disposable microplates with 96 wells and 30,000 cells per well were used. After incubation for $24 \mathrm{~h}$ at $37{ }^{\circ} \mathrm{C}$ in an atmosphere of $5 \% \mathrm{CO}$, the supernatant was discarded and $100 \mu \mathrm{L}$ of 1:2 serial dilutions of each extract was added to a separate well with 2 repetitions for each dilution. The dilutions ranged from $1.8 \mu \mathrm{g} / \mathrm{mL}$ to $2,000 \mu \mathrm{g} / \mathrm{mL}$. The microplates were incubated again for at least $96 \mathrm{~h}$. The first dilution of extract that did not induce morphological changes in cells, by light microscopy, was considered the MNTC.

The MTT colorimetric assay was evaluated as previously described in Barros et al., 2013 using the reduction of 3-(4, 5dimetilazol-2-il)-2,5-difeniltetrazolium bromide (Sigma-Aldrich, Brazil)tocalculate the cytotoxic concentration to $50 \%$ of cell culture $\left(\mathrm{CC}_{50}\right)$.

\section{Antiviral assay}

The antiviral activity was assayed according to methods described previously, using a viral cytopathic effect inhibitory assay (Koseki et al., 1990; Simoni et al., 1996). The microplates were seeded with $3.0 \times 10^{4}$ cells at $100 \mu \mathrm{L} /$ well and incubated at $37^{\circ} \mathrm{C}$ and $5 \% \mathrm{CO}_{2}$ for $24 \mathrm{~h}$. The media was discarded, and the cells in each well were treated with $100 \mu \mathrm{L}$ of extract at the determined MNTC. The microplates were kept in an incubator for $1 \mathrm{~h}$ at $37^{\circ} \mathrm{C}$ and $5 \% \mathrm{CO}_{2}$. After this period, the viral suspensions in logarithmic dilutions were added to a group of three or four wells for each dilution. The microplates were incubated again for at least $72 \mathrm{~h}$. The viral titer was calculated using the Reed and Muench method (1938) to determine the $\operatorname{TCDI}_{50 / 100 \mu \mathrm{L}}$. The antiviral activity was calculated as the difference between the titer of the treated cells (T) for control cells(C) $(\log \mathrm{T} / \log \mathrm{C})$ and expressed aspercent of viral inhibition according to PI $=[1$-(Titer of treated/Titer of control)] x 100 (Felipe et al., 2006) or as viral inhibition according to Silva et al., 2016. The Phosphonoformic acid trisodium salt hexahydrate (Foscarnet Sigma ${ }^{\circledR}$ ) at $250 \mu \mathrm{g} / \mathrm{mL}$ was used as positive control in antiviral assay.

The MTT colorimetric assay was made for calculated the $50 \%$ inhibitory concentration $\left(\mathrm{IC}_{50}\right)$ using the OriginPro 8 program and the values obtained from nonlinear regression. The selectivity index (SI) was calculated from the ratio $\mathrm{CC}_{50}$ over $\mathrm{IC}_{50}$.

\section{Statistical analysis}

The statistical analysis was performed using the log values of the lower concentration of virus that caused cytopathic effect in the presence and absence of extract in the treated $(\mathrm{T})$ and control (C) tests, respectively. These values were used in the Tukey's test, with a $\mathrm{P}$ value $<0.01$ considered significant.

\section{RESULT AND DISCUSSION}

\section{Phytochemical analysis}

HPLC analysis of crude hydroalcoholic extract from leaves of D. brasiliensis from collection of August/2008 (Figure 1) showed the predominance of three main compounds. After several chromatographic steps were obtained three flavonoids:quercetrin (1), astilbin (2) and isoastilbin (3). The structures of these compounds were characterized by comparison of spectral data, mainly ${ }^{1} \mathrm{H}$ and ${ }^{13} \mathrm{C}$ NMR, with those previously reported in the literature 2
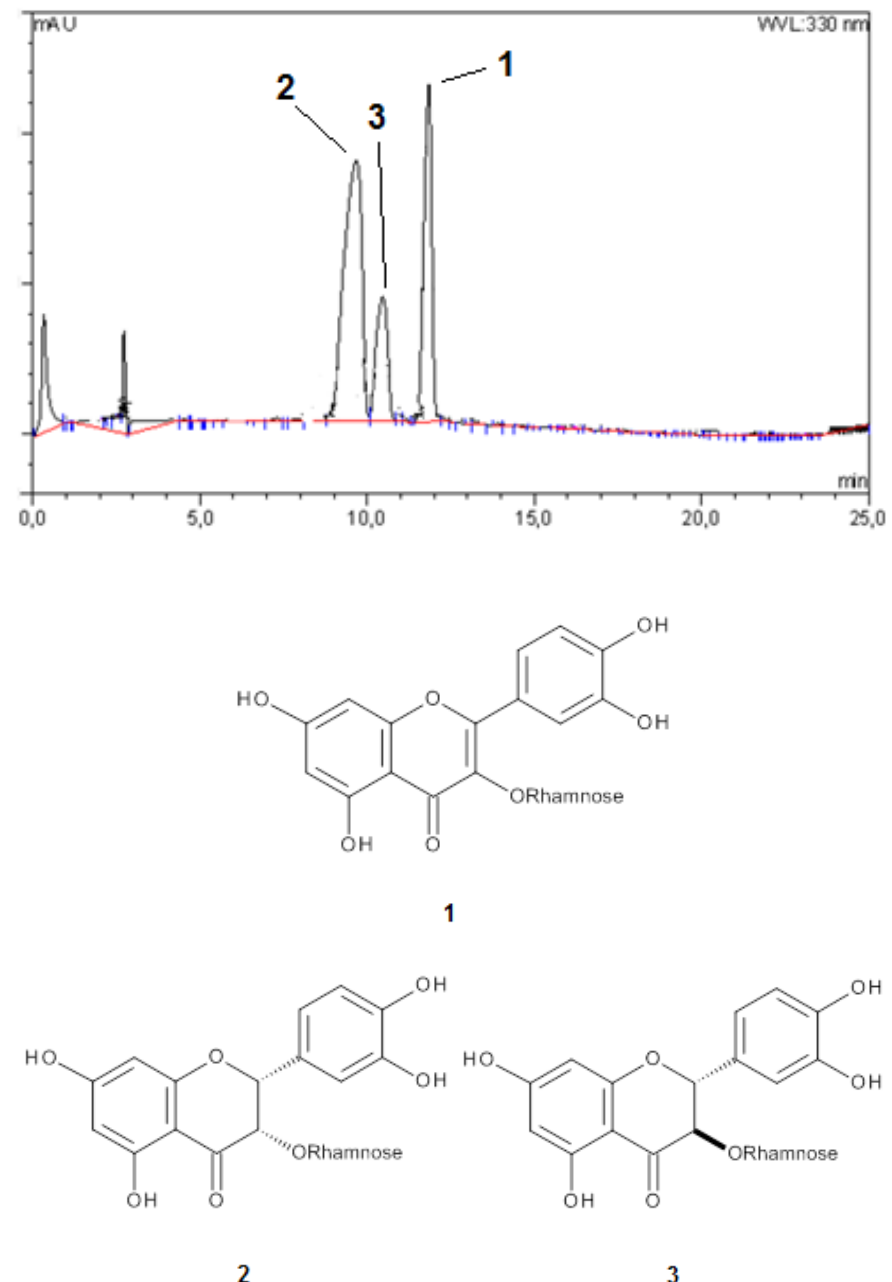

Fig. 1: HPLC chromatogram $(\lambda=330 \mathrm{~nm})$ of hydroalcoholic extract from leaves of $D$. brasiliensis and structures of compounds $\mathbf{1}-\mathbf{3}$. 


\section{Cytotoxicity assays}

The maximum non-toxic concentration (MNTC) ranged from $31.25 \mu \mathrm{g} / \mathrm{mL}$ to $125 \mu \mathrm{g} / \mathrm{mL}$ in Vero cells and $62.5 \mu \mathrm{g} / \mathrm{mL}$ to $500 \mu \mathrm{g} / \mathrm{mL}$ in MDBK cells. In general, MDBK cells were more resistant to tested extracts compared with Vero cells, with high MNTCvalues in all cases.

The MTT assay were made with crude hydroalcoholic extract from leaves of $D$. brasiliensis from collection of August/2008 for BoHV-1 and from collection of April/2009 for EHV-1. The cytotoxic concentration at $50 \%$ in Vero cells was $>100 \mu \mathrm{g} \mathrm{ml}^{-1}$, and the inhibitor concentrations at 50\%, for EHV-1 was $25.33 \mu \mathrm{g} \mathrm{ml}^{-1}$ with selectivity index value of $>3.95$. The cytotoxic concentration at $50 \%$ in MDBK cells was $664.1 \mu \mathrm{g} \mathrm{ml}^{-1}$ and the inhibitor concentrations at $50 \%$, for BoHV-1 was $86.25 \mu \mathrm{g}$ $\mathrm{ml}^{-1}$ with selectivity index value of 7.69.

\section{Antiviral activity}

Table 1 shows the results of antiviral activity against EHV-1 and BoHV-1, of the hydroalcoholic extracts and statistical analysis of each sample with control. All extracts showed inhibitory effects against bovine herpesvirus. In the case of BoHV1 , the percentage of inhibition (PI) was highest than $99 \%$ and it was significant relative to control. With regard to EHV, not all samples showed viral inhibition, it was observed in only three collections and it was significant relative to control.

In a comparison among each one of the collections, there was a greater similarity between the inhibition rate of the collection of Aug/08 and Oct/08, and Jun/09 against BoHV-1 but there was no significant difference between them in any of the comparisons. In addition, the collections of Dec/2008, Feb/2009 and Apr/09 showed viral inhibition against EHV-1 from other collections that was not exhibited antiviral activity.

Table 1: Hydroalcoholic extracts from leaves of D. brasiliensis (six samples August/2008 to June/2009):cytotoxicity,viral inhibition and percentage of inhibition against EHV-1in Vero cells and BoHV-1 in MDBK cells.

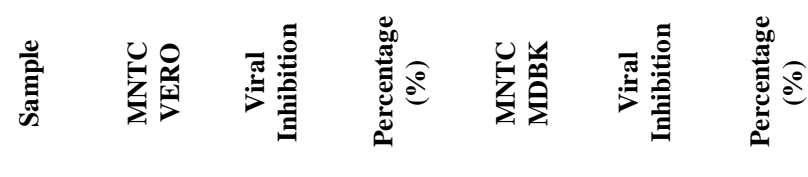

\begin{tabular}{ccccccc}
\hline & $\boldsymbol{\mu g} / \mathbf{m L}$ & $\mathbf{E H V - 1}$ & $\mathbf{E H V}-\mathbf{1}$ & $\boldsymbol{\mu g} / \mathbf{m L}$ & $\mathbf{B o H V}-1$ & BoHV-1 \\
\hline Aug/2008 & 62.5 & 0 & 0.00 & 250 & 5.5 & $99.99^{\mathrm{a}}$ \\
Oct/2008 & 125 & 0 & 0.00 & 250 & 5.24 & $99.99^{\mathrm{a}}$ \\
Dec/2008 & 31.2 & 1.74 & $98.18^{\mathrm{a}}$ & 62.5 & 4.5 & $99.99^{\mathrm{a}}$ \\
$\mathrm{Feb} / 2009$ & 62.5 & 1.88 & $98.68^{\mathrm{a}}$ & 125 & 5.5 & $99.99^{\mathrm{a}}$ \\
Apr/2009 & 31.2 & 1.83 & $98.52^{\mathrm{a}}$ & 62.5 & 3.0 & $99.90^{\mathrm{a}}$ \\
Jun/2009 & 31.2 & 0 & 0.00 & 125 & 5.91 & $99.99^{\mathrm{a}}$ \\
\hline
\end{tabular}

MNTC:maximum non-toxic concentration;EHV-1 - equine herpesvirus, BoHV-1 - bovine herpesvirus; ${ }^{a}$ - significant result compared to control; Foscarnet presented percentage of inhibition of $99.9 \%$ onBoHV -1 and $82.6 \%$ against EHV-1.

In the present study, different hydroalcoholic extracts from leaves of $\mathrm{D}$. brasiliensis displayed antiviral activity against animal herpesviruses mainly for bovine herpesvirus (BoHV-1) and these results showed to be independent of the collection date. Otherwise, the cytotoxicity of the extracts observed on Vero and MDBK cells for the six samples collected during a period of one year (August 2008 to June 2009) was different, being the lowest cytotoxicity detected in the Oct/08 sample while the Apr/09 sample was the most cytotoxic for both cells. At the time of collection of the sample with the lowest cytotoxicity (Oct/08), flowers were observed in the plant, suggesting a phenological effect. Gobbo-Neto and Lopes (2007) described an increase of secondary metabolites in Tanacetum parthenium in the early stages of plant development, before the appearance of flowers. This period is related to an increased production of secondary metabolites involved in the attraction of insect to pollinate the plant.

The antiviral activity of extracts against EHV-1 in Vero cells was lower compared to the activity against BoHV-1 in MDBK cells. Variations in antiviral activity from these extracts may be due to differences in the viral envelope structure, which alters the interaction between the viruses and plant compounds. Chiang et al. (2002) demonstrated an antiviral effect of the soluble phenolic compounds of Plantago major, caffeic acid and chlorogenic acid, against herpesvirus. On the other hand, the methanol and ethanol extracts of $P$. major reported by McCutcheon et al. (1995) and tested against herpesvirus did not exhibit antiviral activity. The ethanol extracts of Youngia japonica showed greater antiviral activity against respiratory syncytial virus than the aqueous extracts, but showed no antiviral activity against herpesviruses (Ooiet al., 2004).

Constituents of medicinal plants with antiviral properties belong to a wide range of substance classes (Beuscher, et al., 1994). Flavonoids are one of these classes, and have been reported to affect virus binding, entry, replication, viral protein translation, formation of certain virus envelope glycoprotein complexes, and viral release (Haslam, 1996; Serkedjieva and Ivancheva, 1999; Felipe et al., 2006; Schnitzler et al., 2008; Gravina et al., 2011).Quercetin is a flavonoid with antiviral activity against several herpesviruses. Gravina et al. (2011) found that quercetin and morin have inhibitory activity against EHV-1. These authors referred to preliminary studies reported by Formica and Regelson (1995) to explain the mode of action of flavonoids and their ability to bind to viral envelope glycoproteins or capsid, suggesting that viral inhibition was related to binding of the aqueous extract to structures in the viral envelope and subsequent inhibition of viral penetration.

In the present study, Drimys extracts were found to contain quercetrin, astilbin and isoastilbin. The astilbin and isoastilbin are water-soluble flavonoids which showed structural similarities to taxifolin. However, taxifolin showed an inhibitory effect on hepatitis A virus replication in vitro, while astilbin and isoastilbin do not have antiviral properties described yet (Biziagos et al., 1987). Quercetrin is also known as bioactive phytochemical for presenting some inhibitory effects (Almeida et al., 1998; Garrett et al., 2012; Chiow et al., 2016). Almeida, et al. (1998) found varied degrees of this activity using Persea americana 
extracts and fractions against SuHV-1. Chiow et al. (2016) observed antiviral activities of Houttuynia cordata extract rich in flavonoids such as quercetin, quercetrin and rutin against murine coronavirus and dengue virus infection. The authors attempted to explain that there is a relation from structural basis and distinct antiviral activities of flavonoids. Hence, quercetin has the hydroxyl group at the R2 position compared to the rhamnose in quercitrin and rubinose in rutin and it was the most bioactive against murine coronavirus and dengue virus. Futhermore, Chiow et al. (2016) related the enhancement of anti-DENV-2 activity of quercetin when combined with quercitrin.

Antiviral drugs available for the treatment of human herpesviruses may also be effective against animal herpesviruses. However, we must be very careful to control such diseases in farm animals. Many of the relevant animals are raised for food and any medication approved for use must firstly to demonstrate safety and efficacy (Newcomer et al., 2014). Akula et al. (2002) demonstrated the ability of genistein to inhibit BoHV-1 replication in cells by inhibiting tyrosine kinase. Genistein is a phytoestrogen found in several plants, including soybeans. The authors hypothesized that cattle feeding soybean products containing high levels of genistein may be beneficial during periods of stress and avoiding reactivation of latent infections. Simoni et al. (2014) demonstrated that plants in the diet of wild pampas and marsh deer living in the Brazilian Pantanal wetland possess antiviral activity against some pathogenic viruses for mammals. Cecropia pachystachya, Melochia villosa, and Polygonum acuminatum presented the most relevant results against BoHV-1 and SuHV-1 while Andira cuyabensis was the most active against avian reovirus.

\section{CONCLUSIONS}

In conclusion, the obtained results demonstrated that the hydroalcoholic extracts of $D$. brasiliensis leaves exhibited strong antiviral activity against bovine and equine herpesviruses. These antiviral activities and other properties demonstrated in several studies indicate that $D$. brasiliensis species is a good option for use in medicinal products, and to complement the care and treatment of farm animals such as cattle or even companion animals such as horses.

\section{ACKNOWLEDGMENTS}

Financial support and sponsorship: We thank to Fundação de Amparo à Pesquisa do Estado de São Paulo (FAPESP) for financial support (Project 2015/11936-2) and fellowship toRMP (Project 2009/01445-0).We also thank CNPq scientific award to JHGL and CAPES scholarships to KHB and MCM.

Conflict of Interests: There are no conflicts of interest.

\section{REFERENCES}

Abreu DCA, Kuniyoshi YSS, Medeiros ACS, Nogueira AC. Caracterização morfológica de frutos e sementes de cataia (Drimys brasiliensis Miers. - Winteraceae). Rev. Bras.deSementes, 2005; 27(2):6774.

Akula SM, Hurley DJ, Wixon RL, Wang C, Christopher CL, Chase DVM. Effect of genistein on replication of bovine herpesvirus type 1. Am J Vet Res, 2002; 63(8):1124-1128.

Barros AV,Conceicao AO, Simoni IC, Padilla MA, Fernandes MJB, Arns CW. In vitro antiviral activity of seeds from Guettarda angelica against avian viruses. J App Pharm Sci,2013;3(07):3133.

Beuscher N, Bodinet C, Neumann-Haefelin D, Marston A, Hostettmann K. Antiviral activity of African medicinal plants. J Ethnopharmacol, 1994; 42(2):101-109.

Biziagos E, Crance JM, Passagot J, Deloince R. Effect of antiviral substances on hepatitis A virus replication in vitro. JMedVirol, 1987; 22(1):57-66.

Boubaker-Elandalousi R, Mekni-Toujani M, Kaabi B, Larbi I, Diouani M-F, Gharbi M, Akkari H, B'chir F, Ghram A. Non-cytotoxic Thymus capitata extracts prevent Bovine herpesvirus-1 infection in cell cultures BMC Vet Res, 2014; 10:231.

Carvalho LAC, Oliveira FS, Toyama DO, Fávero AO, Romoff P, Lago JHG. Avaliação do potencial antinociceptivo e análise fitoquímica do extrato e do óleo volátil das folhas de Drimys brasiliensis. Reunião Anual da Sociedade Brasileira de Química, Águas de Lindóia, SP, 2008. [ONLINE] Available at: http://sec.sbq.org.br/cdrom/31ra/resumos/T00402.pdf [Accessed 06Dec 2016].

Chiang LC, Chiang W, Chang MY, NgLT, Lin CC. Antiviral activity of Plantago major extracts and related compounds in vitro. Antiviral Res, 2002; 55(1):53-62.

Chiow KH, Phoon MC, Putti T, Tan BKH, Chow VT. Evaluation of antiviral activities of HouttuyniacordataThunb. extract, quercetin, quercetrin and cinanserin on murine coronavirus and dengue virus infection. Asian Pac J Trop Med, 2016;9(1):1-7.

Claudino VD, da Silva KC, Cechinel Filho V, Yunes RA, DelleMonache F, Giménez A, Salamanca E, Gutierrez-Yapu D, Malheiros, A. Drimanes from Drimysbrasiliensis with leishmanicidal and antimalarial activity. Mem Inst Oswaldo Cruz, 2013; 108(2):140-4.

Du Q, Li L, Jerz G. Purification of astilbin and isoastilbin in the extract of Smilax glabra rhizome by high-speed counter-current chromatography. J.Chromatogr. A., 2005;1077:98-101.

Felipe AMM, Rincão VP, Benati FJ, Linhares REC, Galina KJ, De Toledo CEM, Lopes GC, De Mello JC, Nozawa C. Antiviral effect of Guazumaulmifolia and Stryphnodendronadstringens on poliovirus and bovine herpesvirus. BiolPharm Bull, 2006; 29(6):1092-1095.

Fernandes MJB, Simoni IC. Caracterização de linhagens celulares: Identificação de espécies por analise isoenzimática. Arq Inst Biol, 1995; 62:59-63.

Formica JV, Regelson, W. Review of biology of quercetin and related bioflavonoids. Food ChemToxicol, 1995;33(12):1061-1080.

Fratoni E, Claudino VD, Yunes RA, FranchiGCJr, Nowill AE, Filho VC, Monache FD, Malheiros A. Further drimanesesquiterpenes from Drimysbrasiliensis stem barks with cytotoxic potential. Naunyn. Schmiedebergs ArchPharmacol, 2016; 389(7):791-7.

Garrett R, Romanos MTV, Borges RM, Santos MG, Rocha L, Silva AJR. Antiherpetic activity of a flavonoid fraction from Ocoteanotata leaves.Braz J Pharmacogn, 2012; 22(2):306-313.

Gravina HD, Tafuri NF, Silva Jr A, Fietto JLR, Oliveira TT, Diaz MAN, Almeida MR. In vitro assessment of the antiviral potential of trans-cinnamic acid, quercetin and morin against equid herpesvirus 1 . Res VetSci, 2011; 91:e158-e162.

Gobbo-Neto LG, Lopes NP. Plantas medicinais: fatores de influência no conteúdo de metabólitos secundários. Quim Nova, 2007; 30(2):374-381.

Gomes MRF,Schuh RS, Jacques ALB, Dorneles GG, Montanha J, RoehePM, BordignonS, DallegraveE, LealMB, Limberger RP.Biological assessment (antiviral and antioxidant) and acute toxicity of essential oils from Drimysangustifolia and D. brasiliensis. Braz J Pharmacogn, 2013; 23(2): 284-290. 
Haslam E. Natural polyphenols (vegetable tannins) as drugs: possible modes of action. J Nat Prod, 1996; 59:205-215.

Koseki I, Simoni IC, Nakamura IT, Noronha AB, Costa SS. Antiviral activity of plant extracts against aphovirus, pseudorabies virus and pestivirus in cell cutures. Microbios Let, 1990; 44:19-30.

Lago JHG, Carvalho LAC, Silva FS, Toyama DO, Fávero OA, Romoff P. Chemical composition and anti-inflammatory evaluation of essential oils from leaves and stem barks from DrimysbrasiliensisMiers (Winteraceae). J Braz ChemSoc, 2010; 21(9):1760-1765.

Lago JHG, Carvalho LAC, Ferreira MJ, Romoff P, Zanin JL, Soares MG, Fávero OA. Intraspecific variation in the essential oils from Drimysbrasiliensis leaves and stem barks. Nat Prod Commun, 2011; 6(2):243-5.

Limberger RP, Scopel M, Sobral M, Henriques AT. Comparative analysis of volatiles from DrimysbrasiliensisMiers and D. angustifoliaMiers (Winteraceae) from Southern Brazil. Biochem System Ecol, 2007; 35(3):130-137.

Malheiros A, Cechinel Filho V, Schmitt CB, Yunes RA, Escalante A, Svetaz L, Zacchino S, Monache FD. Antifungal activity of drimanesesquiterpenes from Drimysbrasiliensis using bioassay-guided fractionation. J Pharm PharmSci, 2005;8(02):335-339.

Markham KR, Ternai B, Stanley R, Geiger H, Mabry TJ. Carbon-13 NMR studies of flavonoids - III: naturally occurring flavonoid glycosides and their acylated derivatives. Tetrahedron, 1978; 34:13891397.

Mecchi MC, Lago JHG. Chemical constituents derived from DrimysbrasiliensisMiers (Winteraceae) Nat Prod Res, 2013; 27:19271929.

MCCutcheon AR, Roberts TE, Gibbons E, Ellis SM, Babiuk LA, Hancock REW, Tower GHN.Antiviral screening of British Colombian medicinal plants. J Ethnopharmacol, 1995; 49(2):101-110.

Newcomer BW, Walz PH, Givens MD. Potential applications for antiviral therapy and prophylaxis in bovine medicine. Anim Health Res Rev, 2014;15(1):102-117.

Ooi LSM, Wang H, Luk CW, Ooi VEC. Anticancer and antiviral activities of Youngia japonica (L.) DC (Asteraceae, Compositae). J Ethnopharmacol, 2004; 94(1):117-122.
Reed LJ, Muench H. A simple method of stimating fifty per cent and point. Am J Hygiene, 1938; 18:493-497.

Schnitzler P, Nolkemper S, Stintzing FC, Reichling J. Comparative in vitro study on the anti-herpetic effect of phytochemically characterized aqueous and ethanolic extracts of Salvia officinalis grown at two different locations. Phytomedicine, 2008; 15:62-70.

Serkedjieva J, Ivancheva S.Antiherpes virus of extracts from the medicinal plant Geranium sanguineum L. J Ethnopharmacol, 1999;64(1):59-68.

Silva ITSS, Fernandes MJB, Oliveira RA, Carvalho LD, Cortez PA, São José AR,Conceicao AO. Annona squamosa L. (annonaceae): chemical bioprospection and biological activity in two phenological stages. AppliedEcolEnviron Res, 2016;14(4):133-147.

Simoni IC, Fernandes MJB, Gonçalves CR, Almeida AP, Costa SS, Lins AP. A study on the a antiviral characteristics of Perseaamericana extracts against Aujesky`s disease virus. Biomedical Let, 1996; 54:173181.

Simoni IC, Manha APS, Sciessere L, Hoe VMH, Takinami VH, Fernandes MJB. Evaluation of the antiviral activity of Brazilian cerrado plants against animal viruses. VirusRev Res, 2007; 12:25-31.

Simoni IC, Fernandes MJB, Camargo LMM, Biltoveni LR, Manha APS, Tomitão MTP, de Oliveira DB, Negrelle R, Costa SS. Plants from deer diet in the Brazilian Pantanal wetland as potential source of antiviral and antioxidant compounds. Virus Rev Res, 2014; 19:1-12.

\section{How to cite this article:}

Parreira RM, Simoni IC, Fávero OA, Lago JHG, Mecchi MC, Barrosa KH, Fernandes MJB. Phytochemical profile andin vitro evaluation of extracts from leaves of Drimysbrasiliensis (Winteraceae) against bovine and equine herpesviruses. J App Pharm Sci, 2017; 7 (07): 122-127. 